\title{
Demodex Species Infestation in Patients with Ear Itching and Its Relationship to Itch Severity
}

\section{Kulak Kaşıntısı Olan Hastalarda Demodex Türlerinin Varlığı ve Kaşınma Şiddeti İle ilişkisi}

\author{
Nagihan Bilal ${ }^{1}$, Özlem Kirişci², Esra Özkaya ${ }^{3}$
}

'Department of Ear-Nose and Throat Diseases, Kahramanmaraş Sütçü Imam University School of Medicine, Kahramanmaraş, Turkey ${ }^{2}$ Microbiology and Parasitology Laboratory, Necip Fazıl City State Hospital, Kahramanmaraş, Turkey

${ }^{3}$ Department of Medical Microbiology, Karadeniz Technical University, Trabzon, Turkey

Cite this article as: Bilal N, Kiriş̧̧i Ö, Özkaya E. Demodex Species Infestation in Patients with Ear Itching and Its Relationship to Itch Severity. Türkiye Parazitol Derg 2017; 41: 87-91.

\section{ABSTRACT}

Objective: The aim of the present study was to investigate Demodex species infestation in patients with ear itching. The relationship between the severity of ear itching and Demodex spp. positivity has not been previously reported in the literature, and we believe that our study will make a significant contribution to the understanding of the etiology of ear itching.

Methods: Fifty patients with itching ears and 54 healthy control patients were asked to use a visual analogue scale (VAS) to rate the itch, the itching period, and the medication used for the itching. All samples were evaluated for Demodex spp. under a light microscope.

Results: There was no statistically significant difference between the groups in terms of numbers of Demodex spp. ( $p=0.154)$, and there was no statistically significant difference between the groups in terms of Demodex spp. positivity $(p=0.054)$. Despite the lack of statistically significant differences, Demodex spp. infestations were more common in the affected group than in the control group. A positive and strongly significant relationship was observed between the number of Demodex spp. and severity of ear itch in the patient group based on VAS scores $(p=0.0001 ; r=0.724)$. Conclusion: We found that an increased number of Demodex spp. was strongly related to increased severity of ear itching.

Keywords: Demodex spp., ear itching, severity of ear itching, external auditory canal

Received: 07.09.2016

Accepted: 08.02.2017

\section{Öz}

Amaç: Çalışmamızın amacı Demodex türlerinin kulak kaşıntısı olan hastalarda infestasyonunu araştırmaktır. Literatürde kulak kaşıntı şiddeti ile Demodex spp. pozitifliği daha önce çalışılmamıştır. Çalışmamızın kulak kaşıntısı etyolojisine büyük katkısı olacağını düşünmekteyiz.

Yöntemler: Kulak kaşıntısı olan 50 hastadan ve olmayan 54 hastadan kaşıntı süresi, kaşıntı için kullandığı ilaçlar ve kaşıntıyı değerlendirmek üzere görsel Analog Skala (VAS skala) doldurması istendi. Bütün örneklerde ışık mikroskobu ile Demodex spp.varlığı araştırıldı.

Bulgular: Demodex spp.varlığının sayısal değerleri gruplar arasında istatistiksel olarak anlamlı farklılık oluşturmadı ( $p=0,154)$. Demodex spp. enfestesyonu tespit edilen gruplar arasında istatistiksel olarak anlamlı farklılık yoktu $(p=0,054)$ ancak hasta grubunda kontrol grubuna oranla daha fazla sayıda Demodex spp. pozitif liği gözlenmiştir. Hasta grubunda Demodex spp. sayısı ve kulak kaşıntı şiddeti (VAS skorları) arasında pozitif yönde istatistiksel olarak anlamlı ve güçlü bir ilişki gözlenmiştir ( $p=0,0001 ; r=0,724)$.

Sonuç: Çalışmamızda Demodex spp. varlığının sayısal değeri ile kulak kaşınma şiddeti arasında güçlü bir doğtu orantı olduğu tesbit edildi.

Anahtar Kelimeler: Demodex spp., kulak kaşıntısı, kulak kaşıntısının şiddeti, dış kulak yolu

Geliş Tarihi: 07.09.2016

Kabul Tarihi: 08.02.2017

\section{INTRODUCTION}

The outer surface of the eardrum and the external auditory canal (EAC) are protected by the tragus-antitragus, the skin cerumen, and the macroscopic defense mechanisms of the EAC isthmus. The cartilaginous canal skin contains hairy cells and cerumen glands such as sebaceous and apocrine glands. These three protective structures form the apopilosebaceous unit. Glandular secretions, which are one part of this primary barrier, mix with the squamous epithelium to form the acidic part of the cerumen (1).

Address for Correspondence / Yazışma Adresi: Nagihan Bilal E.mail: nagihanyazan@gmail.com 
The external auditory canal is a self-cleaning structure, and the cerumen has a number of important antimicrobial properties. The cerumen is a lipid film that protects the EAC skin, lowers the $\mathrm{pH}$ level, and contains lysozymes, thereby creating an unfavorable environment for pathogens (2).

Chronic ear itching is a complex problem with many potential etiologies. It must be kept in mind in the differential diagnosis that it might be due to various illnesses-such as EAC carcinoma, contact dermatitis, seborrheic dermatitis, psoriasis, and dermatomycosis-or to a dermatophytid (id) reaction (3). The etiology of isolated chronic itching of the EAC is commonly thought to be allergic contact dermatitis (4).

In practice, ear, nose, and throat (ENT) physicians frequently encounter patients with isolated chronic itching of the EAC, defined as "itchy ear syndrome" in the literature. Its typical clinical symptoms are itching, burning, prickling, and pain. The severity of the itching varies from mild to a level that prevents sleep. On ENT examination, including anamnesis and microscopic otoscopy, these patients will usually have no findings indicative of a bacterial infection, active dermatological disease (such as psoriasis or atopic dermatitis), or otomycosis (5).

The parasite Demodex folliculorum is a member of the Demodicidae family, forming a part of the prostigmata, and was first reported by Henle and Berger in 1841. It was described in detail by Simon in 1842, while another variant, D. brevis, was described by Akbulutova in 1963 (6).

$D$. folliculorum and D. brevis live on the human body and are thought to transmit between humans through close contact (7-9). D. folliculorum is a transparent mite with a length of $0.3 \mathrm{~mm}$, and mature $D$. folliculorum are usually observed in numbers below 5 mites $/ \mathrm{cm}^{2}$ in the population (10). This mite is found more frequently in the face region (head, nose, cheek, nasolabial sulcus, and eyelids) and in areas with more sebum, and it is also sometimes found on the scalp and chest. Demodex spp. infestation might be increased in immunosuppressed patients $(8,11)$.

A Demodex spp. infestation is considered pathogenic when it penetrates the dermis and increases in number of mites. This metazoan leads to diseases such as pityriasis folliculorum, papulopustular rosacea, granulomatous rosacea, inflammatory papule, acne vulgaris, perioral dermatitis, blepharitis, and folliculitis $(9,12-14)$. In recent studies, Demodex spp. infestation has been observed to increase in diabetic patients, especially those with uncontrolled blood glucose levels and itching (15). D. folliculorum has been observed in patients with itching in the EAC (16). Demodex spp. are seen more often in those using systemic steroids and those with immune failure. They are also thought to be related to ear itching in those using local steroids in the EAC (16).

The aim of our study was to investigate infestations of Demodex spp. parasites in patients with itching ears. The severity of ear itching and Demodex spp. positivity has not been previously studied in the literature. The relationship of ear itching with Demodex spp. was evaluated in patients not using steroids. We believe that our work will be a significant contribution to the understanding of the etiology of ear itching.

\section{METHODS}

In accordance with the Helsinki II Declaration, prior to the beginning of this study all participants signed an informed consent form provided by the Ethics Committee.

A total of 104 patients over the age of 18 were evaluated between December 2015 and March 2016. Dermatologic disease related to the skin of the EAC, infection, otomycosis, chronic or acute otitis media, masses of the external ear canal, congenital ear anomalies, and steroid use were the exclusion criteria for the study.

The 50 patients with itching ears were asked to use a visual analogue scale (VAS) to evaluate the itch, the period of itching, and the medications used for the itch. After a routine ENT examination, skin samples were taken from the tragus medialis of the external ear canal with a curette. The samples were quickly delivered to the laboratory in the form of glycerin-containing preparations. Using the same procedure, samples were taken from the tragus medialis of the 54 patients who did not have ear itching and whose VAS scores were 0 . These samples were also analyzed for parasites (Figure 1).

\section{Statistical Analysis}

The data were analyzed with Statistical Packages for the Social Sciences version 18.0 (SPSS Inc., Chicago, IL, USA). Continuous variables were presented as mean \pm standard deviation, and categorical variables were expressed as numbers and percentages. When parametric test assumptions were met, the test of the significance of the difference between two means was used for the comparison of independent group differences. When parametric test assumptions were not met, the Mann-Whitney $U$-test was used for the comparison of independent group differences. A chi-square analysis was used for the comparison of categorical variables, and Spearman's correlation analysis was used for the analysis of the relationships between numerical variables.

\section{RESULTS}

Of the 104 patients included in the study, 50 formed the group with ear itching and 54 formed the control group without ear

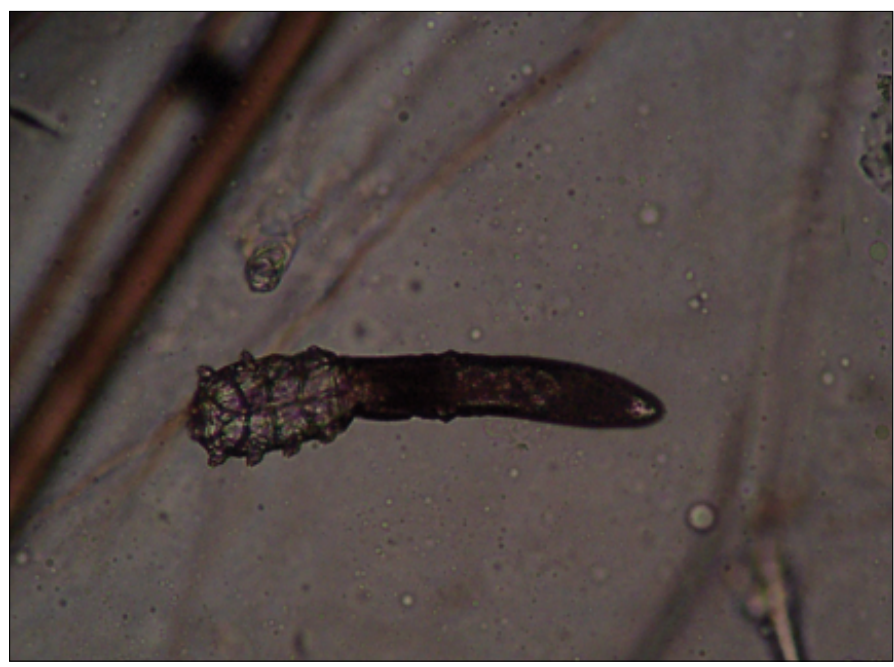

Figure 1. Demodex folliculorum in the examined preparations 
itching (Table 1). There was no statistically significant difference between the groups in terms of gender distribution $(p=0.432)$. The mean age of the patient group with ear itching was $44 \pm 16.49$ years, while the mean age of the control group was $43 \pm 15.48$ years, with no statistically significant difference observed $(p=0.4)$. The mean itching period in the patient group was $36.26 \pm 50.38$ days, and the mean VAS score for the severity of itching was $5.36 \pm 2.3$. The mean number of Demodex spp. was $8.54 \pm 10.38$ mites $/ \mathrm{cm}^{2}$ in the patient group and $3.69 \pm 3.27$ mites $/ \mathrm{cm}^{2}$ in the control group, with no statistically significant difference between the groups $(p=0.154)$. There was greater positivity of Demodex spp. in the patient group than in the control group, but the difference was not statistically significant $(p=0.054)$ (Table 2).

No statistically significant relationship was observed between age and the number of Demodex spp. in the patient group or the control group ( $p=0.418$ and $p=0.089$, respectively). There was no statistically significant difference between gender and Demodex spp. positivity in the patient group or the control group $(p=0.906$ and $p=0.332$, respectively).

A statistically significant and strong positive relationship was observed in the patient group between the number of Demodex spp. and the severity of ear itching based on VAS scores $(p=0.0001 ; r=0.724)$ (Figure 2).

\section{DISCUSSION}

In this study, a positive correlation was determined between the severity of ear itching and the numbers of Demodex spp., which have been proposed to be involved in the etiology of ear itching.

D. folliculorum is commonly found on the face, cheeks, nose, scalp, EAC, hair follicles of the eyes, and areas with abundant sebaceous secretion. It is also found on normal skin after birth,

Table 1. Gender ratio of patient and control groups

\begin{tabular}{|c|c|c|c|c|c|}
\hline & \multicolumn{2}{|c|}{ Group } & \multirow[b]{2}{*}{ Total } \\
\hline & & & Patient & Control & \\
\hline \multirow[t]{4}{*}{ Gender } & \multirow[t]{2}{*}{ Male } & $n$ & 23 & 29 & 52 \\
\hline & & $\%$ & $46.0 \%$ & $53.7 \%$ & $50.0 \%$ \\
\hline & \multirow[t]{2}{*}{ Female } & $n$ & 27 & 25 & 52 \\
\hline & & $\%$ & $54.0 \%$ & $46.3 \%$ & $50.0 \%$ \\
\hline \multirow{2}{*}{\multicolumn{2}{|c|}{ Total }} & $n$ & 50 & 54 & 104 \\
\hline & & $\%$ & $100 \%$ & $100 \%$ & $100 \%$ \\
\hline
\end{tabular}

Table 2. Demodex spp. positivity in patient and control groups

\begin{tabular}{|c|c|c|c|c|c|}
\hline & \multicolumn{2}{|c|}{ Group } & \multirow[b]{2}{*}{ Total } \\
\hline & & & Patient & Control & \\
\hline \multirow{4}{*}{$\begin{array}{l}\text { Demodex } \\
\text { spp. } \\
\text { infestation }\end{array}$} & \multirow[t]{2}{*}{ Negative } & $n$ & 25 & 37 & 62 \\
\hline & & $\%$ & $50.0 \%$ & $68.5 \%$ & $59.6 \%$ \\
\hline & \multirow[t]{2}{*}{ Positive } & $n$ & 25 & 17 & 42 \\
\hline & & $\%$ & $50.0 \%$ & $31.5 \%$ & $40.4 \%$ \\
\hline \multirow{2}{*}{\multicolumn{2}{|c|}{ Total }} & $n$ & 50 & 54 & 104 \\
\hline & & $\%$ & $100 \%$ & $100 \%$ & $100 \%$ \\
\hline
\end{tabular}

and its numbers rise with increased sebaceous secretions during puberty. D. folliculorum is found on the skin of $20 \%-80 \%$ of normal people at less than 5 mites $/ \mathrm{cm}^{2}(17,18)$. It is generally found in women more often than in men (19); however, in our study, there was no significant difference between the genders. Demodex spp. infestation is also thought to increase with age (20). However, in several studies, its relationship with age has not been found to be significant $(9,21,22)$. In our study as well, no significant difference was observed between age and Demodex spp. infestation.

While Demodex spp. infestations can occur through direct contact with the skin of an affected person, they can also occur indirectly through the use of infested objects such as towels, combs, blankets, beds, and clothing (19). According to the literature, the most common symptoms associated with facial Demodex spp. are a burning sensation of the skin, tightness of the skin itching, and dry skin $(11,23)$.

D. folliculorum is a saprophytic mite found in the pilosebaceous glands of the human body (11). The EAC includes hair follicles and sebaceous and apocrine glands. The combination of the squamous epithelium of the EAC with secretions from the glands forms a serum with cerumen, and this protects the EAC from infection $(2,3)$. It has been reported that $D$. folliculorum and $D$. brevis may be located in the ciliary follicles and sebaceous glands of the EAC (13). The relationship of Demodex spp. infestation with the use of steroids has been reported in the literature $(4,7)$. In a study by Çevik et al, a statistically significant difference with respect to ear itching was observed in those using local steroids compared with those not using steroids (16). In the current study, only individuals not using any local or systemic steroids and with no immune disorders were included. Thus, by discounting other factors from the etiology, the role of Demodex spp. could be investigated in relation to ear itching.

Demodex spp. are thought to play a role in skin diseases, and more than 5 mites $/ \mathrm{cm}^{2}$ is considered pathogenic (24). It has been reported in recent years that Demodex spp. might play a role

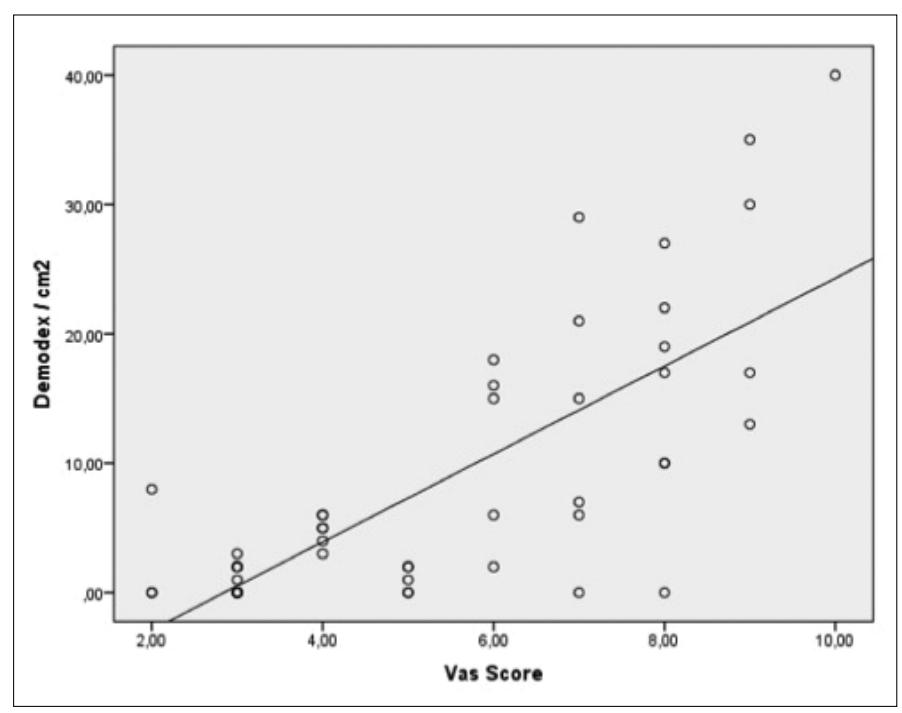

Figure 2. Correlation curve between Demodex spp. numbers and VAS scores for the severity of ear itching in the patient group 
in the etiopathogenesis of rosacea, acne vulgaris, blepharitis, perioral dermatitis, pustular folliculitis, papulopustular lesions of the scalp, and the pustular lesions of acquired immunodeficiency syndrome (25-28). Demodex spp. are also thought to play a role in chronic blepharitis-caused eye diseases (29). Their presence in patients with chronic renal disease, cancer, and immune deficiencies, such as those caused by malnutrition, suggests that they are an opportunistic parasite (30-32). However, when compared with control groups in previous studies, it has been shown that Demodex spp. are not an opportunistic parasite in cases of immune deficiency (33). Chronic itching of the ear is a complex problem with many different etiologies, and it must be kept in mind during the differential diagnosis that the itching might be due to various diseases such as EAC carcinoma, contact dermatitis, seborrheic dermatitis, psoriasis, and dermatomycosis- or to dermatophytid (id) reaction (3). Allergic contact dermatitis is most commonly thought to be the main etiology of isolated chronic EAC itching (4). Many studies related to the etiology of ear itching have been performed. Ding et al. carried out a study that examined the ear secretions of 613 high school students and found the Demodex spp. rate to be $11.8 \%$. In addition, they determined that the rate of Demodex spp. infestations was higher in those with itching ears than in those without (34). Çevik et al. detected a significant difference in the incidence of Demodex spp. between patients with ear itching who used a local steroid and those who did not, but no significant difference was detected between normal individuals and those with ear itching (16). Likewise, in our study no significant difference was found in Demodex spp. number or positivity between patients with ear itching and the control group, but Demodex spp. positivity was observed more often in the affected group. This result is consistent with the literature. In conclusion, a statistically significant and strong positive relationship was detected between the Demodex spp. number and the severity of ear itching.

\section{CONCLUSION}

In the present study, samples from 104 patients were analyzed for Demodex spp. infestation as an etiology of ear itching. We determined that Demodex spp. infestation was an important factor in the participants with ear itching and that increased numbers of Demodex spp. were strongly related to increased severity of ear itching.

Ethics Committee Approval: Approval for the study was granted by the Ethics Committee of Sutcu Imam University of Medical Sciences (Decision Date: 25/01/2016 Decision No: 16).

Informed Consent: Informed consent was obtained from the voluntary patients in the study.

Peer-review: Externally peer-reviewed.

Author Contributions: Concept - N.B., E.Ö.; Design - N.B.; Supervision - N.B., Ö.K., E.Ö.; Materials - N.B., Ö.K.; Data Collection and/or Processing - N.B., Ö.K., E.Ö.; Analysis and/or Interpretation - N.B., E.Ö.; Literature Review - N.B.; Writing - N.B.; Critical Review - N.B.; Other - N.B.

Conflict of Interest: No conflict of interest was declared by the authors.

Financial Disclosure: The authors declared that this study has received no financial support.
Etik Komite Onayı: Bu çalışma için etik komite onayı Kahramanmaraş Sütçü İmam Üniversitesi Tıp Fakültesi Bilimsel Araştırmalar Etik Kurulu'ndan alınmıştır (Karar tarihi: 25/01/2016 Karar No: 16).

Hasta Onamı: Yazılı hasta onamı bu çalışmanın gönüllü katılımcılarından alınmıştır.

Hakem Değerlendirmesi: Dış bağımsız.

Yazar Katkıları: Fikir - N.B., E.Ö.; Tasarım - N.B.; Denetleme - N.B., Ö.K., E.Ö.; Veri Toplanması ve/veya İşlemesi - N.B., Ö.K., E.Ö; Analiz ve/veya Yorum - N.B., E.Ö.; Literatür Taraması - N.B.; Yazıyı Yazan - N.B.; Eleştirel inceleme - N.B.

Çıkar Çatışması: Yazarlar çıkar çatışması bildirmemişlerdir.

Finansal Destek: Yazarlar bu çalışma için finansal destek almadıklarını beyan etmişlerdir.

\section{REFERENCES}

1. Acar B, Babademez MS, Karabulut H, Genc S, Karasen RM. Refractory Isolated Pruritic External Auditory Canals. KBB-Forum 2008; 7 : 59-62.

2. Pabla $L$, Jindal $M$, Latif $K$. The management of otitis externa in UK general practice. Eur Arch Otorhinolaryngol 2012; 269: 753-6. [CrossRef]

3. Derebery J, Berliner KI. Foot and ear disease the dermatophytid reaction in otology. Laryngoscope 1996; 106: 181-6. [CrossRef]

4. Li LY, Cruz PD Jr. Allergic contact dermatitis: pathophysiology applied to future therapy. Dermatol Ther 2004; 17: 219-23. [CrossRef]

5. King WP. Allergic disorders in the otolaryngologic practice. Otolaryngol Clin North Am 1985; 18: 677-90.

6. Akbulatova LK. The pathogenic role of the mite Demodex and the clinical form of demodicosis in man. Vestn Dermatol Venerol 1966; 40: 57-61.

7. Nutting WB. Hair follicle mites (Acari: Demodicidae) of man. Int J Dematol 1976; 15: 78-9. [CrossRef]

8. Ozcelik S, Sumer Z, Degerli S, Ozyazıcı G, Hayta SB, Akyol M et al. The incidence of Demodex folliculorum in patients with chronic kidney deficiency. Turkiye Parazitol Derg 2007; 31: 66-8.

9. Aycan OM, Otlu GH, Karaman U, Daldal N, Atambay M. Frequency of the appearance of Demodex sp. in various patient and age groups . Turkiye Parazitol Derg 2007; 31: 115-8.

10. Forton F, Germaux MA, Brasseur T, De Liever A, Laporte M, Mathys $C$, et al. Demodicosis and rosacea: epidemiology and significance in daily dermatologic practice. J Am Acad Dermatol 2005; 52: 74-87. [CrossRef]

11. BenkSilfeler D, Keskin Kurt R, Kaya OA, Yengil E, Hamamci B, Okyay $A G$, et al. Demodex Folliculorum in polycystic ovary syndrome patients. Eur Rev Med Pharmacol Sci 2015; 19: 1141-5.

12. Crawford GH, Pelle MT, James WD. Rosacea: I. Etiology, pathogenesis, and subtype classification. J Am Acad Dermatol 2004; 51: 327-41. [CrossRef]

13. Shelley WB, Shelley ED, Burmeister V. Unilateral demodectic rosacea. J Am Acad Dermatol 1989; 20: 915-7. [CrossRef]

14. Sibenge S, Gawkrodger DJ. Rosacea: a study of clinical patterns, blood flow, and the role of Demodex folliculorum. J Am Acad Dermatol 1992; 26: 590-3. [CrossRef]

15. Gokce C, Aycan Kaya O, Yula E, Ustun I, Yengil E, Sefil F, et al. The effect of blood glucose regulation on the presence of opportunistic Demodex folliculorum mites in patients with type 2 diabetes mellitus. J Int Med Res 2013; 41: 1752-8. [CrossRef]

16. Cevik C, Kaya OA, Akbay E, Yula E, Yengil E, Gulmez MI, et al. Investigation of demodex species frequency in patients with a persistent itchy ear canal treated with a local steroid. J Laryngol Otol 2014; 128: 698-701. [CrossRef] 
17. Norn MS. Demodex folliculorum. Incidence, regional distribution, pathogenicity. Dan Med Bull 1971; 18: 14-7.

18. Andrews JR. The prevalence of hair follicle mites in Caucasian New Zealanders. N Z Med J 1982; 95: 451-3.

19. Ziolkowska JR, Nokiel M, Fleischer M. Demodex an old pathogen or new one? Adv Clin Exp Med 2014; 23: 295-8. [CrossRef]

20. Elston DM. Demodex mites: facts and controversies. Clin Dermatol 2010; 28: 502-4. [CrossRef]

21. Firat PY, Gecit I, Depecik F, Karadan M, Karcı E, Karaman U, et al. Demodex spp. positivity among laboratory staff, kitchen staff, cleaning workers and nurses working in a state hospital. Turkiye Parazitol Derg 2010; 34: 164-7. [CrossRef]

22. Kaya M, Hamamci B, Cetinkaya U, Yaman O,Yazar S. Investigation of Demodex sp. Using Cellophane Tape Method in Foreign Male Students in a High School. Turk Hijyen ve Deneysel Biyoloji Dergisi 2010; 67: 73-7.

23. Jansen T, Kastner U, Kreuter A, Altmeyer P. Rosacea-like demodicidosis associated with acquired immunodeficiency syndrome. $\mathrm{Br} \mathrm{J}$ Dermatol 2001; 144: 139-42. [CrossRef]

24. Askin U, Seckin D.Comparision of the two techniques for measurement of the density of Demodexfolliculorum: standardized skin surface biopsy and direct microscopic examination. Br J Dermatol 2010; 162: 1124-6. [CrossRef]

25. Baima B, Sticterling M. Demodicidosis revisited. Acta Derm Venereol 2002; 82: 3-6. [CrossRef]

26. Magro CM, Crowson AN. Necrotizing eosinophilic folliculitis as a manifestation of the atopic diathesis. Int J Dermatol 2000; 39: 672-7. [CrossRef]
27. Roihu T, Kariniemi AL. Demodex mites in acne rosacea. J Cutan Pathol 1998; 25: 550-2. [CrossRef]

28. Yucel A, Y,Imaz M. Investigation of the prevalence of Demodex folliculorum and Demodex brevis in rosacea patients. Turkiye Parazitol Derg 2013; 37: 195-8. [CrossRef]

29. Wesolowska M, Knysz B, Reich A, Blazejewska D, Czarnecki M, Gladysz $A$, et al. Prevalence of Demodex spp. in eyelash follicles in different populations. Arch Med Sci 2014; 10: 319-24. [CrossRef]

30. Inci M, Kaya OA, Yula E, Gokce H, Rifaioglu MM, Demirtas O, et al. Investigating Demodex folliculorum in patients with urological cancer. Turkiye Parazitol Derg 2012; 36: 208-10. [CrossRef]

31. Kaya S, Selimoglu MA, Kaya OA, Ozgen U. Prevalence of Demodex folliculorum and Demodex brevis in childhood malnutrition and malignancy. Pediatr Int 2013; 55: 85-9. [CrossRef]

32. Yagdiran Duzgun O, Aytekin S. Comparison of Demodex folliculorum density in haemodialysis patients with a control group. J Eur Acad Dermatol Venereol 2007; 21: 480-3. [CrossRef]

33. Kosik-Bogacka DI, Lanocha N, Lanocha A, Czepita D, Grobelny A, Zdziarska B, et al. Demodex folliculorum and Demodex brevis in healthy and immunocompromised patients. Ophthalmic Epidemiol 2013; 20: 159-63. [CrossRef]

34. Ding $Y$, Huang $X$. Investigation of external auditory meatus secretion Demodex folliculorum and Demodex brevis infection in college students. Lin Chuang Er Bi Yan Hou Ke Za Zhi 2005; 19: 176-7. 